Acta Agroph., 2018, 25(2), 163-174

doi: $10.31545 /$ aagr/92544

\title{
ASSESSMENT OF THE USE OF FLOUR FROM THE GRAIN OF SPRING COMMON WHEAT CULTIVATED UNDER ORGANIC FARMING FOR PASTA PRODUCTION
}

\author{
Magdalena Gońda ${ }^{1}$, Grażyna Cacak-Pietrzak ${ }^{2}$, Krzysztof Jończyk ${ }^{3}$ \\ ${ }^{1}$ Department of Grain Processing and Bakery \\ Prof. Wacław Dąbrowski Institute of Agricultural and Food Biotechnology \\ Rakowiecka 36, 02-532 Warsaw, Poland \\ ${ }^{2}$ Department of Food Technology, Division of Cereal Technology \\ Warsaw University of Life Sciences \\ Nowoursynowska 159c, 02-787 Warsaw, Poland \\ ${ }^{3}$ Department of Systems and Economics of Crop Production \\ Institute of Soil Science and Plant Cultivation, State Research Institute \\ Czartoryskich 8, 24-100 Pulawy, Poland \\ e-mail: magdalena.gonda@ibprs.pl
}

Abstract. The aim of the study was the assessment of the possibility of using flour from the grain of 12 common wheat varieties (Bombona, Brawura, Kandela, Katoda, Łagwa, Monsun, Ostka Smolicka, Parabola, Trappe, Tybalt, Werbena, Żura) cultivated under organic farming conditions for pasta production. The scope of the study included the evaluation of dough susceptibility to darkening, pasta preparation, and evaluation of its quality. A majority of pasta doughs obtained from tested wheat flour was characterised by an average susceptibility to darkening. Requirements of the pasta industry in relation to susceptibility to darkening were not met in the case of Kandela, Werbena and Żura varieties. Total ash content in the pasta ranged from 0.54 to $0.64 \%$ dry mass (DM) and total protein content from 8.6 to $10.3 \%$ DM. Despite the low protein content, the losses of dry matter of pasta during cooking were not high (4.8-6.6\%), and the increase in their mass (2.9-3.3 times) was comparable to commercial pasta (2.8 times). The pasta was also highly rated in terms of sensory evaluation. On the basis of the conducted study, flours from grain of Bombona, Brawura, Katoda, Monsun, Parabola and Tybalt wheat varieties were selected as potential raw material for the production of pasta.

Keyw ords: wheat, organic, pasta, chemical composition, texture, sensory evaluation 


\section{INTRODUCTION}

Correct selection of raw materials for the production of pasta is important, as their physicochemical properties affect not only the process of pasta production but also the final quality of the products (Wójtowicz 2006, Chillo et al. 2007, Lucisano et al. 2008). Pasta of good quality should be characterised by golden-amber colour, smooth and semi-transparent surface, glassy fracture, and it should not be brittle. Such pasta is obtained from the products of milling of grain of durum wheat (Triticum durum). In some countries, including Poland, pasta is often produced with the use of flour from the grain of common wheat (T. aestivum ssp. vulgare), commonly cultivated in our country (Ciołek et al. 2013, Sicignano et al. 2015).

A large selection of pastas is available on the Polish market, both of local production and imported. Among those one can find organic pastas produced from various raw materials: semolina, spelt, rye, buckwheat, barley or rice flours (CacakPietrzak et al. 2016). However, compared to pastas from conventional production, they are less easily available, and their prices are notably higher.

The market does not offer organic pastas from flour of the grain of common wheat, commonly available in Poland, and therefore the objective of the study was the assessment of the possibility of using flour from the grain of selected cultivars of common wheat from organic farming as a raw material for pasta production.

\section{MATERIAL AND METHOD}

The experimental material consisted of 12 pastas produced under laboratory conditions from flour from the grain of spring cultivars of common wheat: Bombona, Brawura, Kandela, Katoda, Łagwa, Monsun, Ostka Smolicka, Parabola, Trappe, Tybalt, Werbena and Żura. The wheat grain originated from a field experiment conducted in 2012 at IUNG-PIB, Puławy (Experimental Station Osiny). The control sample was commercial pasta produced from flour from common wheat grain.

Wheat grain was ground using a laboratory mill, Brabender Quadrumat Senior (milling yield 70-72\%). The first stage of the assessment of the applicability of the flours for pasta production was the determination of the susceptibility of the doughs prepared from the to darkening, on the basis of colour change of sample cakes thermostated at $30^{\circ} \mathrm{C}$ for 3 hours (Obuchowski 1997). The colour change of pasta doughs was estimated visually and rated in a three-degree scale (I - no darkening, II - slight darkening, III - strong darkening), and with the use of a photocolorimeter (Minolta CR-200), in the CIE L*a*b* colour system. Based on the results of dough colour measurements before and after the thermostating the absolute colour difference $\Delta \mathrm{E}$ was determined (Chmiel et al. 2011). 
In the next stage of the study pasta doughs with moisture of $36 \%$ were prepared using the Kitchen Aid appliance. The doughs were prepared from $200 \mathrm{~g}$ of flour and water at temperature of $30^{\circ} \mathrm{C}$. Kneaded doughs with homogeneous structure were rolled to the thickness of $2 \mathrm{~mm}$ and cut to the form of spaghetti using an attachment for the Kitchen Aid. Pasta formed into nests was dried for 2 hours in a convective drier at temperature of $60^{\circ} \mathrm{C}$, and then, after a 2 hour rest period, they were dried to the water content of $12 \%( \pm 0.1 \%)$.

In the dried pastas the following assays were performed: total protein content with the Kjeldahl method (Nx5,7) (PN-EN ISO 20483:2014-02), total ash content (PN-EN ISO 2171:2010), and product hardness by means of the texture analyser type TA-XT2i. In the shear test a tooth-shaped head was used, with nominal force of $0.5 \mathrm{~N}$, at feed rate of $0.1 \mathrm{~mm} \mathrm{~s}^{-1}$ (Operation Manual 1997).

Samples of the pastas, with mass of $100 \mathrm{~g}$, were cooked in $1000 \mathrm{~cm}^{3}$ of water. The cooking time was selected individually for every sample (until the disappearance of white core in cross-section). In the case of the commercial pasta the cooking time applied was that recommended by the producer. After cooking the pasta was weighed and then the weight gain indices were calculated and the dry matter loss during cooking was determined (Obuchowski 1997). Estimation of the mechanical features of the pastas was conducted with the use if the texture analyser type TA-XT2i (TPA test). The measurements were made using a cylindrical attachment with diameter of $25 \mathrm{~mm}$. The feed speed of the working element was $1 \mathrm{~mm} \mathrm{~s}^{-1} .30$ and $70 \%$ compression of samples was applied, and the gap between the pressings of the compression element was $10 \mathrm{~s}$. Based on the results obtained the elasticity, cohesiveness, hardness, gumminess and chewiness were calculated (Petitot et al. 2009). Cooked pastas were subjected also to sensory evaluation. Each of the evaluated traits (appearance, shape, colour, flavour and taste, other traits) were rated from 1 (least desirable) to 5 (most desirable) points. The results of the sensory evaluation are given in the paper as mean values for the traits listed above. The evaluation was conducted by a trained fifteen-person team of jurors.

The results obtained were processed using the statistical software package Statgraphics Centurion XVI. All the data concerning the analysed parameters were subjected to statistical analysis using the single-factor analysis of variance ANOVA. The significance of differences of the mean values was determined with Tukey's test at significance level of $\alpha=0.05$.

\section{RESULTS AND DISCUSSION}

An important indicator in the assessment of the applicability of flour for pasta production is the determination of the susceptibility of dough obtained from it to darkening. The results of such a determination allow to estimate the intensity and direction of changes of pasta dough colour in the course of subsequent production 
phases and to predict the colour of the end product. Unfavourable colour changes are caused by the activity of enzymes from the group of hydrolases (mainly endoand exopeptidases) and oxidoreductases (polyphenyloxidases and lipo-oxidases). Flours that doughs produced of display a low susceptibility to darkening are good raw material for pasta production (Rachoń 2004).

For the analysed pasta doughs, the values of parameter $\mathrm{L}^{*}$, describing the lightness of colour, were statistically differentiated (Tab. 1). For doughs analysed immediately after preparation, the values of that parameter fell within the range of 80.44-83.04. In a study conducted by Rachon et al. (2002) the colour lightness L* of fresh pasta doughs obtained from wholemeal flour of common wheat grain was similar, with average value of 81.0 .

Table 1. Results of the evaluation of changes in the colour of the pasta dough

\begin{tabular}{|c|c|c|c|c|c|c|c|}
\hline \multirow{3}{*}{ Cultivar } & \multicolumn{7}{|c|}{ Colour of pasta dough } \\
\hline & \multicolumn{2}{|c|}{$\mathrm{L}^{*}(-)$} & \multicolumn{2}{|c|}{$a^{*}(-)$} & \multicolumn{2}{|r|}{$\mathrm{b}^{*}(-)$} & $\Delta \mathrm{E}$ \\
\hline & 0 ' & $3^{\prime}$ & 0 ' & 3 ' & 0 ' & 3' & \\
\hline Bombona & $82.74 \mathrm{abc}$ & $76.28 \mathrm{a}$ & $-0.67 \mathrm{f}$ & $0.83 \mathrm{e}$ & $16.43 \mathrm{bc}$ & $14.99 \mathrm{de}$ & $6.8 \mathrm{bcd}$ \\
\hline Brawura & $82.88 \mathrm{ab}$ & $75.98 \mathrm{ab}$ & -0.54 ef & $1.04 \mathrm{de}$ & $16.93 \mathrm{ab}$ & $16.24 \mathrm{ab}$ & $7.1 \mathrm{abcd}$ \\
\hline Kandela & $82.25 \mathrm{abcd}$ & $73.59 \mathrm{de}$ & $0.05 \mathrm{bcd}$ & $1.61 \mathrm{bc}$ & $15.23 \mathrm{def}$ & $16.04 \mathrm{abc}$ & $8.9 \mathrm{a}$ \\
\hline Katoda & $80.44 \mathrm{f}$ & $74.72 \mathrm{bcd}$ & $0.07 \mathrm{bcd}$ & $1.63 \mathrm{bc}$ & $17.47 \mathrm{a}$ & $16.58 \mathrm{a}$ & $6.0 \mathrm{~d}$ \\
\hline Łagwa & $81.71 \mathrm{cde}$ & $75.54 \mathrm{abc}$ & $-0.20 \mathrm{~d}$ & $1.37 \mathrm{~cd}$ & $14.73 \mathrm{fg}$ & $15.14 \mathrm{cde}$ & $6.4 \mathrm{~cd}$ \\
\hline Monsun & 81.93 bcde & $75.93 \mathrm{ab}$ & $0.16 \mathrm{bc}$ & $1.58 \mathrm{bc}$ & $15.16 \mathrm{def}$ & $15.05 \mathrm{de}$ & $6.2 \mathrm{~d}$ \\
\hline Ostka Smolicka & $82.50 \mathrm{abc}$ & $74.60 \mathrm{bcd}$ & $-0.12 \mathrm{~cd}$ & $1.83 \mathrm{ab}$ & $15.80 \mathrm{~cd}$ & 15.69 abcde & $8.2 \mathrm{abc}$ \\
\hline Parabola & $83.04 \mathrm{a}$ & $76.31 \mathrm{a}$ & $-0.23 \mathrm{de}$ & $1.09 \mathrm{de}$ & $15.52 \mathrm{de}$ & 15.40 bcde & $6.8 \mathrm{bcd}$ \\
\hline Trappe & 81.35 def & $72.89 \mathrm{e}$ & $0.37 \mathrm{ab}$ & $2.14 \mathrm{a}$ & 15.74 cde & 15.46 bcde & $8.7 \mathrm{ab}$ \\
\hline Tybalt & 80.97 ef & $74.21 \mathrm{cde}$ & $0.56 \mathrm{a}$ & $2.06 \mathrm{a}$ & $14.42 \mathrm{~g}$ & $14.80 \mathrm{e}$ & $6.9 \mathrm{bcd}$ \\
\hline Werbena & 81.24 def & $72.75 \mathrm{e}$ & $0.51 \mathrm{a}$ & $2.04 \mathrm{a}$ & 15.07 efg & $15.73 \mathrm{abcd}$ & $8.7 \mathrm{ab}$ \\
\hline Żura & $82.22 \mathrm{abcd}$ & $75.10 \mathrm{abcd}$ & $0.05 \mathrm{bcd}$ & $1.46 \mathrm{c}$ & $15.34 \mathrm{def}$ & 15.57 bcde & $7.3 \mathrm{abcd}$ \\
\hline
\end{tabular}

Values denoted with the same letter indices (a-g) within a column are not significantly different statistically at the level of $\alpha=0.05 ; 0$ ' - measurement of fresh pasta, 3'- measurement of pasta after 3-hour temperature cycle

After 3-hour thermostating the colour lightness $\mathrm{L}^{*}$ of all samples of dough decreased, which indicates darkening of their colour (change towards grey). The lowest value of parameter $L^{*}$ (72.75) was characteristic of dough from flour from the grain of wheat cultivar Werbena, while the highest value, as in the case of direct evaluation, dough from flour from grain of wheat cultivar Parabola (76.31). Unfavourable colour changes during the thermostating of pasta dough obtained from wholemeal flour from grain of common wheat are indicated also in the result of the study by Rachon et al. (2002). 
The values of the colour parameter $\mathrm{a}^{*}$ were statistically differentiated (Tab. 1). For the analysed pasta doughs evaluated immediately after preparation the values fell within the range from -0.67 to 0.56 . After 3 -hour thermostating the values of that parameter increased for all evaluated dough samples (0.83-2.14).

The values of the colour parameter $b^{*}$, like those of lightness $L^{*}$, were statistically differentiated (Tab. 1). For doughs evaluated immediately after preparation they varied from 14.42 to 17.47 . After 3-hour thermostating the values of that parameter generally decreased, with the exception of doughs obtained from flour from grain of wheat cultivars Kandela, Łagwa, Tybalt, Werbena and Żura.

The absolute colour difference $(\Delta \mathrm{E})$ of the fresh and thermostated pasta doughs varied from 6.0 to 8.9 (Tab. 1). The lowest values of that parameter were obtained for doughs from flour from grain of wheat cultivars Katoda, Lagwa and Monsun, and the highest from flour from grain of wheat cultivars Kandela, Trappe and Werbena. According to the International Commission on Illumination (CIE), $\Delta \mathrm{E}$ values above 3.5 indicate a significant colour change (Chmiel et al. 2011). The values of $\Delta \mathrm{E}$ of all analysed samples of pasta dough were higher than 3.5 , which means that the changes in their colour that occurred during thermostating were significant - identifiable even by an inexperienced observer.

Visual comparison of colour of the fresh and thermostated pasta doughs confirmed the changes in their colour determined instrumentally. None of the analysed samples of pasta dough was qualified in the group with low susceptibility to darkening ( $1^{\text {st }}$ degree). Most of the analysed doughs were characterised by medium susceptibility to darkening $\left(2^{\text {nd }}\right.$ degree). Doughs obtained from flour from grain of wheat cultivars Kandela, Werbena and Żura were classified in the group with high susceptibility to darkening ( $3^{\text {rd }}$ degree). According to the standard PN-A-74020:1993, flours that doughs produced from display a high susceptibility to darkening should not be used for pasta production. On this basis one can conclude that the organic flours evaluated in this study, from grain of wheat cultivars Kandela, Werbena and Żura, do not meet the raw material requirements of the pasta industry.

The content of mineral components (ash) in pastas produced from flour from wheat grain from organic farming varied from 0.54 to $0.64 \% \mathrm{DM}$ and was statistically differentiated (Tab. 2). The lowest ash content was characteristic of pastas from flour from grain of wheat cultivars Katoda and Brawura, and the highest - from cultivars Werbena, Trappe and Żura. In terms of the content of mineral components, pastas produced in laboratory conditions did not differ from the commercial pasta and from pastas of flour from common wheat grain studied by Romankiewicz et al. (2014). According to Sobota and Skwira (2009), the content of mineral components in pastas from common wheat flour is usually in the range of $0.45-0.50 \% \mathrm{DM}$, 
which results from the common use of flours type 450 and 500 for their production. With an increase in ash content there is a deterioration in the colour and in the cooking properties of pastas (Vetrimani et al. 2005, Bagdi et al. 2014).

Table 2. Results of evaluation of physiochemical properties of pasta

\begin{tabular}{lccc}
\hline \multicolumn{1}{c}{ Cultivar } & $\begin{array}{c}\text { Total ash content } \\
(\% \mathrm{DM})\end{array}$ & $\begin{array}{c}\text { Total protein content } \\
(\% \mathrm{DM})\end{array}$ & $\begin{array}{c}\text { Hardness } \\
(\mathrm{N})\end{array}$ \\
\hline Bombona & $0.57 \mathrm{abc}$ & $9.4 \mathrm{de}$ & $33.3 \mathrm{ab}$ \\
Brawura & $0.56 \mathrm{bc}$ & $9.3 \mathrm{de}$ & $22.2 \mathrm{efg}$ \\
Kandela & $0.61 \mathrm{ab}$ & $9.3 \mathrm{de}$ & $18.4 \mathrm{fg}$ \\
Katoda & $0.54 \mathrm{c}$ & $9.6 \mathrm{~cd}$ & $37.9 \mathrm{a}$ \\
Lagwa & $0.60 \mathrm{abc}$ & $9.1 \mathrm{ef}$ & $29.2 \mathrm{bcd}$ \\
Monsun & $0.59 \mathrm{abc}$ & $9.5 \mathrm{cde}$ & $35.3 \mathrm{ab}$ \\
Ostka Smolicka & $0.57 \mathrm{abc}$ & $8.6 \mathrm{f}$ & $31.7 \mathrm{~b}$ \\
Parabola & $0.57 \mathrm{abc}$ & $9.4 \mathrm{de}$ & $31.2 \mathrm{bc}$ \\
Trappe & $0.63 \mathrm{ab}$ & $9.4 \mathrm{de}$ & $24.6 \mathrm{def}$ \\
Tybalt & $0.59 \mathrm{abc}$ & $10.0 \mathrm{bc}$ & $33.3 \mathrm{ab}$ \\
Werbena & $0.64 \mathrm{a}$ & $10.3 \mathrm{~b}$ & $17.5 \mathrm{~g}$ \\
Zura & $0.62 \mathrm{ab}$ & $10.2 \mathrm{~b}$ & $32.8 \mathrm{ab}$ \\
Control/Pattern & $0.59 \mathrm{abc}$ & $11.2 \mathrm{a}$ & $25.0 \mathrm{cde}$ \\
\hline
\end{tabular}

Values denoted with the same letter indices (a-g) within a column are not significantly different statistically at the level of $\alpha=0.05$

Total protein content in pastas produced under laboratory conditions was statistically differentiated and varied from 8.6 to $10.3 \% \mathrm{DM}$ (Tab. 2). The highest content of that component was characteristic of pastas from flour from grain of wheat cultivars Werbena, Żura and Tybalt, and the lowest from cultivar Ostka Smolicka. Total protein content in the commercial pasta $(11.2 \% \mathrm{DM})$ was significantly higher, and higher protein content was also characteristic of commercial pastas of common wheat flour studied by Romankiewicz et al. (2014). The relatively low total protein content in the analysed pastas resulted from the low content of that component in the flours from which they were produced. The flours were from the milling of grain of common wheat which, compared to other species, has a lower content of proteins (Rachon et al. 2011). In addition, the grain was from organic farming, in which the use of mineral fertilisation with nitrogen is prohibited, which causes that protein content in grain can even be less than 9.0\% (Sobolewska 2016). In commercial organic pastas produced from flour from grain of various wheat species, studied by Cacak-Pietrzak et al. (2016), the total content of protein varied from $10.7 \% \mathrm{DM}$ (wholemeal semolina) to $14.7 \%$ DM (wholemeal spelt flour). Commercial pastas studied by Gałkowska et al. (2012) had total protein content from 10.0\% DM (common wheat flour) to $14.6 \% \mathrm{DM}$ (semolina). Similar levels of that component $(10.0-11.0 \% \mathrm{DM})$ in pastas from flour from common wheat grain are indicated also 
by the results of a study conducted by Martinez et al. (2007). According to Baiano et al. (2007), protein content has a strong impact on pasta quality. Pasta with a low protein content is more brittle and susceptible to breaking, there are greater losses of dry mass during cooking, the pasta is more easily overcooked and is less firm.

The hardness of pastas produced from flour from wheat grain from organic farming varied from 17.5 to $37.9 \mathrm{~N}$ and was statistically differentiated (Tab. 2). The commercial pasta was characterised by a somewhat lower hardness $(25.0 \mathrm{~N}) \mathrm{com}$ pared to the mean value of that parameter for the laboratory pastas $(29.0 \mathrm{~N})$. The hardness of commercial organic pastas studied by Cacak-Pietrzak et al. (2016) was also statistically differentiated (9.9-58.6 N) and depended on the kind of raw material used in their production. The highest hardness was characteristic of pastas produced from semolina from durum wheat grain, and the lowest of pasta from spelt flour.

For pastas produced from flours from wheat grain from organic farming the values of the weight increase index varied from 2.9 to 3.3 and were not statistically differentiated (Tab. 3). The commercial pasta had a slightly lower weight increase index value. In the study by Cacak-Pietrzak et al. (2016), the values of that index for organic commercial pastas were more varied and depended on the kind of raw material from which they were produced. Pastas from semolina were characterised by lower weight increase than pastas from spelt flour.

Table 3. Results of evaluation of cooking properties of pasta

\begin{tabular}{lccc}
\hline \multicolumn{1}{c}{ Cultivar } & $\begin{array}{c}\text { Weight increase index } \\
(-)\end{array}$ & $\begin{array}{c}\text { Dry mass losses of pasta } \\
\text { during cooking } \\
(\%)\end{array}$ & $\begin{array}{c}\text { Sensory evaluation } \\
\text { (pts.) }\end{array}$ \\
\hline Bombona & $3.1 \mathrm{a}$ & $4.8 \mathrm{~b}$ & $4.3 \mathrm{a}$ \\
Brawura & $3.1 \mathrm{a}$ & $5.8 \mathrm{ab}$ & $4.3 \mathrm{a}$ \\
Kandela & $3.3 \mathrm{a}$ & $5.9 \mathrm{ab}$ & $4.3 \mathrm{a}$ \\
Katoda & $3.0 \mathrm{a}$ & $5.6 \mathrm{ab}$ & $4.1 \mathrm{a}$ \\
Łagwa & $3.1 \mathrm{a}$ & $6.6 \mathrm{a}$ & $4.2 \mathrm{a}$ \\
Monsun & $3.2 \mathrm{a}$ & $5.4 \mathrm{ab}$ & $4.4 \mathrm{a}$ \\
Ostka Smolicka & $3.1 \mathrm{a}$ & $6.1 \mathrm{ab}$ & $4.1 \mathrm{a}$ \\
Parabola & $3.1 \mathrm{a}$ & $6.0 \mathrm{ab}$ & $4.2 \mathrm{a}$ \\
Trappe & $3.2 \mathrm{a}$ & $5.8 \mathrm{ab}$ & $4.0 \mathrm{a}$ \\
Tybalt & $3.0 \mathrm{a}$ & $4.8 \mathrm{~b}$ & $4.2 \mathrm{a}$ \\
Werbena & $2.9 \mathrm{a}$ & $6.0 \mathrm{ab}$ & $4.1 \mathrm{a}$ \\
Żura & $3.2 \mathrm{a}$ & $6.2 \mathrm{ab}$ & $4.0 \mathrm{a}$ \\
Control/Pattern & $2.8 \mathrm{a}$ & $6.8 \mathrm{a}$ & $4.3 \mathrm{a}$ \\
\hline
\end{tabular}

Explanatory notes as in Tab. 2

According to Obuchowski (1997), for good quality pasta the loss of dry mass during cooking should not be higher than $8.0 \%$. All of the analysed pasta met this requirement. Dry mass losses during the cooking of the pastas produced under laboratory conditions varied from 4.8 to $6.6 \%$ and were lower than those of the 
commercial pasta (Tab. 3). Similar losses of dry mass during the cooking of commercial pastas produced from flour from common wheat grain (4.4-6.4\%) were observed in a study by Martinez et al. (2007). Whereas, in the study by CacakPietrzak et al. (2016) the losses for commercial organic pastas produced from flour from grain of various wheat species were more diversified and varied from $3.8 \%$ (semolina) to $14.7 \%$ (wholemeal spelt flour).

The team conducting sensory evaluation of the pastas after cooking had no reservations concerning their taste and flavour. Pastas produced from flour from wheat grain from organic cultivation were generally characterised by adequate form and an absence of conglutination. The greatest diversity related to the colour of the pastas. Most samples were characterised by uniform creamy colour. Creamy colour with a noticeable grey hue was characteristic of pastas produced from flour from grain of wheat cultivars Kandela, Łagwa, Trappe, Werbena and Żura. The sensory evaluation team awarded the highest rating to pastas prepared from flour from grain of wheat cultivars Monsun (4.4 pts), Bombona, Brawura and Kandela (4.3 pts.) (Tab. 3). A comparable mean rating (4.3 pts.) was awarded to the commercial pasta which differed from the pastas prepared under laboratory conditions mainly by a more yellowish colour. However, some of the jurors considered the colour of that pasta as too intensive and "artificial", and indicated it is one of the main shortcoming of that pasta.

The texture of pasta after cooking is one of the more important indicators determining the acceptability of the product to the consumers. Good quality pasta should be characterised by suitable firmness, springiness, and non-excessive cohesiveness. The estimation of pasta texture is commonly performed using the TPA test, during which pasta is subjected to double compression (Sozer et al. 2007, Petitot et al. 2009).

Springiness, on the basis of which we can determine to what degree the product resumes its initial form after compression, varied for the analysed pastas from 0.68 to 0.84 and was not statistically differentiated (Tab. 4). In a study by Dziki et al. (2012), the values of that parameter for semolina pastas fell within the range from 0.52 to 0,60 . Similar values were obtained by Olivera and Salvadori (2009) for organic pasta produced from wholemeal wheat flour.

Cohesiveness is a parameter determining the rate at which the product undergoes disintegration under the effect of external forces (Sozer et al. 2007). The cohesiveness of pastas produced from flour from wheat grain from organic farming varied from 0.26 to 0.37 and was lower compared to that of the commercial pasta (0.46) (Tab. 4). Somewhat higher cohesiveness was characteristic of wholemeal organic pastas studied by Olivera and Salvadori (2009), and pastas from semolina studied by Petitot et al. (2009).

Hardness expresses indirectly the firmness of pasta (Dziki et al. 2012). The hardness of pastas from flour from wheat grain from organic farming varied from 2.92 to $5.40 \mathrm{~N}$ (Tab. 4). The commercial pasta had a significantly higher hardness $(11.87 \mathrm{~N})$. 
Higher hardness was also characteristic of the wholemeal organic pastas studied by Olivera and Salvadori (2009). Whereas, in the study by Petitot et al. (2009), the values of that parameter for pastas from semolina varied from 3.14 to $3.71 \mathrm{~N}$.

Chewiness and gumminess are parameters describing the energy necessary to chew the product down to a form that allows it to be swallowed (Sozer et al. 2007). The gumminess of pastas from flour from wheat grain from organic farming varied from 0.89 to $1.77 \mathrm{~N}$, and chewiness varied from 0.70 to $1.43 \mathrm{~N}$ (Tab. 4). The values of those parameters were significantly lower compared to those of the commercial pasta.

Table 4. Results of evaluation of the texture of pasta

\begin{tabular}{lccccc}
\hline & \multicolumn{4}{c}{ Texture analysis - double compression test (TPA) } \\
\cline { 2 - 5 } \multicolumn{1}{c}{ Cultivar } & $\begin{array}{c}\text { Springiness } \\
\text { Bombona }\end{array}$ & Cohesiveness & Hardness & Gumminess & Chewiness \\
\hline Brawura & $0.79 \mathrm{a}$ & $0.32 \mathrm{~b}$ & $3.91 \mathrm{~b}$ & $1.23 \mathrm{~b}$ & $0.98 \mathrm{~b}$ \\
Kandela & $0.81 \mathrm{a}$ & $0.33 \mathrm{ab}$ & $5.40 \mathrm{~b}$ & $1.77 \mathrm{~b}$ & $1.43 \mathrm{~b}$ \\
Katoda & $0.78 \mathrm{a}$ & $0.30 \mathrm{~b}$ & $4.63 \mathrm{~b}$ & $1.43 \mathrm{~b}$ & $1.11 \mathrm{~b}$ \\
Lagwa & $0.79 \mathrm{a}$ & $0.30 \mathrm{~b}$ & $3.55 \mathrm{~b}$ & $1.06 \mathrm{~b}$ & $0.84 \mathrm{~b}$ \\
Monsun & $0.82 \mathrm{a}$ & $0.33 \mathrm{ab}$ & $4.58 \mathrm{~b}$ & $1.52 \mathrm{~b}$ & $1.24 \mathrm{~b}$ \\
Ostka Smolicka & $0.78 \mathrm{a}$ & $0.26 \mathrm{~b}$ & $3.42 \mathrm{~b}$ & $0.89 \mathrm{~b}$ & $0.70 \mathrm{~b}$ \\
Parabola & $0.75 \mathrm{a}$ & $0.39 \mathrm{ab}$ & $4.44 \mathrm{~b}$ & $1.75 \mathrm{~b}$ & $1.30 \mathrm{~b}$ \\
Trappe & $0.68 \mathrm{a}$ & $0.35 \mathrm{ab}$ & $3.60 \mathrm{~b}$ & $1.27 \mathrm{~b}$ & $0.87 \mathrm{~b}$ \\
Tybalt & $0.77 \mathrm{a}$ & $0.37 \mathrm{ab}$ & $4.27 \mathrm{~b}$ & $1.60 \mathrm{~b}$ & $1.27 \mathrm{~b}$ \\
Werbena & $0.80 \mathrm{a}$ & $0.31 \mathrm{~b}$ & $4.79 \mathrm{~b}$ & $1.49 \mathrm{~b}$ & $1.20 \mathrm{~b}$ \\
Żra & $0.84 \mathrm{a}$ & $0.31 \mathrm{~b}$ & $5.05 \mathrm{~b}$ & $1.60 \mathrm{~b}$ & $1.37 \mathrm{~b}$ \\
Control/Pattern & $0.73 \mathrm{a}$ & $0.34 \mathrm{ab}$ & $2.92 \mathrm{~b}$ & $1.00 \mathrm{~b}$ & $0.73 \mathrm{~b}$ \\
\hline
\end{tabular}

Explanatory notes as in Tab. 2

\section{CONCLUSIONS}

1. Pasta doughs prepared in laboratory conditions from flour from grain of analysed wheat cultivars differed significantly in terms of colour lightness $\mathrm{L}^{*}$. After 3 -hour temperature cycle the values of that parameter for all dough samples decreased, which indicates a darkening of their colour (towards grey). The difference in colour between fresh and thermostated pasta doughs was significant $(\Delta \mathrm{E}>3.5)$.

2. Visual comparison of colour of fresh and thermostated pasta doughs confirmed the changes in their colour determined instrumentally. None of the analysed samples of pasta dough was classified in the group with low susceptibility to darkening. Most of the analysed doughs were characterised by medium susceptibility to darkening. Doughs produced from flour from grain of wheat cultivars Kandela, 
Werbena and Żura were classified in the group with high susceptibility to darkening. In industrial conditions this would constitute the grounds to reject those cultivars as raw material for pasta production.

3. The organic pastas produced in laboratory conditions differed in terms of their content of mineral components $(0.54-0.64 \% \mathrm{DM})$, total proteins $(8.6-10.3 \%$ $\mathrm{DM})$ and hardness (17.5-37.9 N). Compared to the commercial pasta, they had a significantly lower content of total proteins.

4. The organic pastas produced in laboratory conditions were characterised by lower dry mass losses during cooking (4.8-6.6\%) and a higher weight increase after cooking (2.9-3.3) compared to the commercial pasta (6.8 and 2.8\%, respectively). Significant differences were also observed in their texture parameters - hardness, gumminess and chewiness.

5. The average number of points awarded by the sensory evaluation team for the organic pastas produced in laboratory conditions varied from 4.0 to $4.4,(0-5 \mathrm{pts}$. scale). In this respect the highest rated were pastas from flour from grain of wheat cultivars Monsun, Bombona, Brawura and Kandela. The mean number of points awarded for sensory properties for the commercial pasta was 4.3.

6. Based on the study, flours from the grain of wheat cultivars Bombona, Brawura, Katoda, Monsun, Parabola and Tybalt were selected as potential raw material for the production of organic pastas.

\section{REFERENCES}

Bagdi A., Szabo F., Gere A., Kokai Z., Sipos L., Tomoskozi S., 2014. Effect of aleurone-rich flour on composition, cooking, textural, and sensory properties of pasta. LWT - Food Sci. Technol., 59, 996-1002.

Baiano A., Conte A., Pati S., Del Nobile M.A., 2007. Influence of protein content and drying temperature on pasta quality. Technica Monitoria International, 58, 84-91.

Cacak-Pietrzak G., Romankiewicz D., Ceglińska A., Lenart E. 2016. Estimation of quality of commercial fusilli-form organic pasta (in Polish). Przegl. Zboż.-Młyn., 60(3), 36-39.

Chillo S., Laverse J., Falcone P.M., Nobile M.A., 2007. Effect of carboxymethylcellulose and pregelatinized corn starch on the quality of amaranthus spaghetti. J. Food Eng., 83, 492-500.

Chmiel M., Słowiński M., Cal P., 2011. Application of computer image analysis for the detection of PSE defect of pork meat (in Polish). Food. Science. Technology. Quality, 6(79), 47-54.

Ciołek A., Makarska E., Rachoń L., 2013. Detection of an addition of flour from common wheat (Triticum aestivum L.) and spelt (Triticum spelta L.) in pasta products from durum wheat (Triticum durum Desf.) (in Polish). Food. Science. Technology. Quality, 6(91), 118-129.

Dziki D., Biernacka B., Laskowski J., 2012. The effect of cooking time and an addition of common wheat flour to semolina on the mechanical properties of spaghetti (in Polish). Acta Agroph., 19(2), 277-287.

Gałkowska D., Pająk P., Fortuna T., Figa B., 2012. Comparison of quality of selected commercial pastas (in Polish). Towaroznawcze Problemy Jakości, 2, 65-77. 
Lucisano M., Pagani M.A., Mariotti M., Locatelli D.P., 2008. Influence of die material on pasta characteristic. Food Res. Int., 41, 646-652.

Martinez C.S., Ribotta P.D., Leon A.E., Añón M.C., 2007. Physical, sensory and chemical evaluation of cooked spaghetti. J. Texture Stud., 38, 666-683.

Obuchowski W., 1997. Technology of industrial production of pasta (in Polish). Wyd. AR Poznań, 53-54, 65-84.

Olivera D., Salvadori V., 2009. Effect of freezing rate in textural and rheological characteristics of frozen cooked organic pasta. J. Food Eng., 90, 271-276.

Petitot M., Brossard Ch., Barron C., Larre C., Morel M., Micard V., 2009. Modification of pasta structure induced by high drying temperatures. Effects on the in vitro digestibility of protein and starch fractions and the potential allergenicity of protein hydrolysates. Food Chem., 116, 401-412.

PN-A-74020:1993. Cereal products. Standard pasta flour (in Polish).

PN-EN ISO 20483:2014-02. Cereal grain and seeds of legumes - Determination of nitrogen content and conversion to protein content -Kjeldahl method (in Polish).

PN-EN ISO 2171:2010. Cereal grain, seeds of legumes and their products - Determination of ash content using the method of combustion (in Polish).

Rachon L., 2004. Estimation of suitability of grain of Polish and foreign lines and cultivars of spring durum wheat (Triticum durum Desf.) for pasta production (in Polish). Biul. IHAR, 231, 129-137.

Rachoń L., Dziamba Sz., Obuchowski W., Kołodziejczyk P., 2002. Estimation of suitability of grain of cultivars of durum wheat (Triticum durum) and common wheat (Triticum aestivum ssp. vulgare) for pasta production (in Polish). Annales UMCS, Sec. E, 57, 77-86.

Rachoń L., Szumiło G., Stankowski S., 2011. Comparison of selected indicators of technological value of common wheat (Triticum aestivum ssp. vulgare), durum wheat (Triticum durum) and spelt wheat (Triticum aestivum ssp. spelta) (in Polish). Fragm. Agron. 28(4), 52-59

Romankiewicz D., Cacak-Pietrzak G., Gońda M., 2014. Estimation of quality of commercial fusilli pasta (in Polish). Acta Agroph., 21(3), 327-335.

Sicignano A., Monaco R., Masi P., Cavella S., 2015. From Raw material to dish: pasta quality step by step. J. Sci. Food Agric., 95(13), 2579-2587

Sobolewska M., 2016. Correlation between protein content and quality traits of winter wheat grain and flour in conventional and organic farming systems (in Polish). Przegl. Zboż.-Młyn., 60(3), 27-29.

Sobota A., Skwira A., 2009. Physical properties and chemical composition of extruded pasta (in Polish). Acta Agroph., 13(1), 245-260.

Sozer N., Dalgic A.C., Kaya A., 2007. Thermal, textural and cooking properties of spaghetti enriched with resistant starch. J. Food Eng., 81, 476-484.

User Manual, 1997. Texture Analyser TA.XT2. Stable Micro System.

Vetrimani R., Sudha M.L., Rao P.H., 2005. Effect of extraction rate of wheat flour on the quality of vermicelli. Food Res. Int., 38, 411-416.

Wójtowicz A., 2006. Effect of semolina moistening and extrusion parameters on selected quality traits of instant pastas (in Polish). Acta Agroph., 8(1), 263-273. 


\title{
OCENA PRZYDATNOŚCI MAZIK Z ZIARNA JARYCH ODMIAN PSZENICY ZWYCZAJNEJ Z UPRAWY EKOLOGICZNEJ DO PRODUKCJI MAKARONÓW
}

\author{
Magdalena Gońda ${ }^{1}$ Grażyna Cacak-Pietrzak ${ }^{2}$, Krzysztof Jończyk ${ }^{3}$
}

${ }^{1}$ Zakład Przetwórstwa Zbóż i Piekarstwa

Instytut Biotechnologii Przemysłu Rolno-Spożywczego im. prof. Wacława Dąbrowskiego

ul. Rakowiecka 36, 02-532 Warszawa

${ }^{2}$ Zakład Technologii Zbóż

Szkoła Główna Gospodarstwa Wiejskiego w Warszawie

ul. Nowoursynowska 159c, 02-787 Warszawa

${ }^{3}$ Zakład Systemów i Ekonomiki Produkcji Roślinnej

Instytut Uprawy Nawożenia i Gleboznawstwa, Państwowy Instytut Badawczy

ul. Czartoryskich 8, 24-100 Puławy

e-mail: magdalena.gonda@ibprs.pl

Streszczenie. Celem pracy była ocena możliwości zastosowania mąki z ziarna 12 odmian pszenicy zwyczajnej (Bombona, Brawura, Kandela, Katoda, Łagwa, Monsun, Ostka Smolicka, Parabola, Trappe, Tybalt, Werbena, Żura) z uprawy ekologicznej jako surowca do produkcji makaronów. Zakres pracy obejmował ocenę podatności ciasta na ciemnienie, przygotowanie makaronów oraz ocenę ich jakości. Stwierdzono, że większość ciast makaronowych otrzymanych z mąki z ziarna ww. odmian pszenicy cechowała się średnią podatnością na ciemnienie. Wymagań przemysłu makaronowego odnośnie podatności na ciemnienie nie spełniały ciasta z mąki z ziarna pszenicy odmian: Kandela, Werbena oraz Żura. Zawartość substancji mineralnych w makaronach wynosiła od 0,54 do $0,64 \%$ s.m., a zawartość białka ogółem od 8,6 do 10,3\% s.m. Pomimo małej zawartości białka straty suchej substancji makaronów podczas gotowania nie były duże (4,8-6,6\%), a przyrost ich masy (2,93,3 razy) był porównywalny z makaronem handlowym (2,8 razy). Makarony zostały również wysoko ocenione pod względem sensorycznym. Na podstawie przeprowadzonych badań jako potencjalny surowiec do produkcji makaronów wytypowano mąki z ziarna pszenicy odmian: Bombona, Brawura, Katoda, Monsun, Parabola i Tybalt.

Słow a klu czow e: pszenica, ekologia, makaron, skład chemiczny, tekstura, ocena sensoryczna 